\title{
Spectroscopical study of natural nanostructured carbonaceous material shungite
}

\author{
A.A.Konchits, B.D.Shanina, M.Ya.Valakh, I.B.Yanchuk, \\ V.O.Yukhymchuk, A.V.Yefanov, S.V.Krasnovyd, M.A.Skoryk * \\ Institute of Semiconductor Physics, National Academy of Sciences of \\ Ukraine, 03028 Kyiv, Ukraine \\ *Nanomedtech LLC, 68 Gorkogo Str., 03680 Kyiv, Ukraine
}

Received March 14, 2014

The correlation between morphology, local structure and magnetic properties of the different origin shungite material with nanocarbon content $25-40$ wt. \% was studied by SEM, EPR, and Raman scattering methods. It was established that structure of the shungite samples is formed by micron size agglomerations of carbon and silicon dioxide clusters with impregnations of pyrite $\left(\mathrm{FeS}_{2}\right)$, iron oxide and aluminium oxide particles. It was found from the Raman data that nanocarbon fraction is formed from $s p^{2}$-hybridized well ordered carbon clusters, size of which increases from $9 \mathrm{~nm}$ up to $12 \mathrm{~nm}$ after annealing of the samples. It was found for the first time that origin of $L 3$ and $L 4$ EPR lines is due to oxy-deficiency centers in the silicon dioxide clusters.

Корреляции между морфологией, особенностями локальной структуры и электронными парамагнитными свойствами образцов шунгита различного происхождения с содержанием наноуглерода 25-40 масс. \% изучались методами СЭМ, ЭПР и комбинационного рассеяния света (КРС). Установлено, что структура шунгита образована смесью агломератов кластеров углерода и диоксида кремния с вкраплениями пирита $\left(\mathrm{FeS}_{2}\right)$, оксидов железа и алюминия. Данные КРС показывают, что наноуглеродная составляющая структуры шунгита образована из упорядоченных $s p^{2}$-гибридизованных углеродных кластеров, размеры которых увеличиваются от 9 нм до 12 нм после отжига образцов. Впервые установлена природа $L 3$ и $L 4$ линий спектра ЭПР шунгита как кислородно-дефицитных $E^{\prime}$ центров в кластерах диоксида кремния.

Спектроскопічне дослідження природного наноструктурованого вуглецевого матеріалу шунгіту. А.А.Кончиць, Б.Д.Шаніна, М.Я.Валах, І.Б.Янчук, В.О.Юхилчук, А.В.Єфанов, С.В.Красновид, М.А.Скорик.

Кореляції між морфологією, особливостями локальної структури та електронними парамагнітними властивостями зразків шунгіту різного походження зі змістом нановуглецю 25-40 мас. \% досліджено методами CEM, ЕПР і комбінаційного розсіювання світла (KPC). Встановлено, що структура шунгіту утворена сумішшю агломератів кластерів вуглецю й діоксиду кремнію із вкрапленнями піриту $\left(\mathrm{FeS}_{2}\right)$, оксидів заліза та алюмінію. Дані КРС показують, що нановуглецева складова структури шунгіту утворена з упорядкованих $s p^{2}$-гібридизованих вуглецевих кластерів, розміри яких збільшуються від 9 нм до 12 нм після відпалу зразків. Вперше встановлено природу L3 і $L 4$ ліній спектра ЕПР шунгіту як киснево-дефіцитні $E^{\prime}$ центри у кластерах діоксиду кремнію. 


\section{Introduction}

Within a class of disordered materials with high conductivity, such as nanoporous carbon, glassy carbon, thin carbon films with $s p^{2}$ dominant hybridization of the electron orbitals, etc, shungite occupies a special place, as natural heterogeneous nanostructured material.

Shungites are carbon-rich rocks of Precambrian age widespread over Karelia (Russia). They are heterogeneous materials consisting predominantly of amorphous silicon dioxide and carbon with nanocarbon content from $5 \%$ up to $98 \%$.The organic matter of shungite is represented by non-crystalline and non-graphitized form of carbon [1, 2].

Shungite has a wide application area due to its abundance and specific properties. The unusual physicochemical and structural properties of shungite are used in diverse industrial and environmental applications including metallurgy, water purification, thermolysis, organosynthesis of cyclic hydrocarbons, etc. Shungite is an effective sorbent for removal of organic and inorganic substances, pathogenic bacteria and heavy metals from contaminated water [1], as well as hydrogen storage in porous shungite $[3,4]$. Unlike to raw coal, shungite is characterized by stability of its properties. Shungite shows unique electrochemical properties due to high resistance to acids as well [5].

Useful practical properties of shungite are known for a long time, but there is not clear scientific evidence for healing properties of shungite. It remains unknown what special features emerge in shungite in a contact with organic material. The controversial is the presence of fullerenes in shungites, which is considered as promising for some medical applications [1, 6-8].

First of all, we need to understand connection between the microstructure of shungite and its physical properties, namely, electron structure, conductivity, magnetic properties, and formation of different defects with temperature and pressure treatment.

In this work, the shungite samples [Sh-II (Zazhogino deposit) and shungite from commercial filter (ShF)] were studied by scanning electron microscopy (SEM), elemental analysis, electron paramagnetic resonance (EPR) and Raman scattering (RS) methods. The aim is to establish a correspondence between the morphology and composition of heterogeneous material shungite, on the one hand, and its electron paramagnetic properties, on the other. On the conceptual stage the SEM images about 10 samples were obtained. During of experiments was proved the fundamental difference between the electronic properties of the samples with a uniform (homogeneous mixing of phases) and non-uniform distribution of phases (presence of extended interfaces between phases). For further studies were selected two "typical" samples, in which there are both areas of dominant phases (carbon or silica) and areas of approximately uniform distribution ( mixing). Properties of samples with non-uniform distribution of phases will subject of a separate study.

\section{Experimental}

Samples of Sh-II and ShF varieties with nanocarbon content 25-40 wt. \% were cut to size of $\sim 3 \times 2 \times 2 \mathrm{~mm}^{3}$ from a single Sh-II lump, as well as from acceptable samples from a shungite commercial filter. Samples were subjected to heat treatment and pumping out during the experiments.

Electron microscopy of the heterogeneous shungite samples was carried out using high-resolution SEM TescanMira 3 MLU; the elemental composition was determined with energy dispersive X-ray spectrometer $\mathrm{X}$-max Oxford Instruments. EPR spectrometer "Radiopan" SE/X-2244 with $100 \mathrm{kHz}$ modulation of the magnetic field was used to measure g-factor values, line width $\Delta H_{p p}$, and spin concentration $N_{s}$. Raman spectra were produced by $\mathrm{Ar}-\mathrm{Kr}$ laser with $\lambda=405 \mathrm{~nm}$ wave-length and registered at the room temperature by means of spectral complex Jobin Ivon T64000.

\section{Results and discussion}

\subsection{Scanning electron microscopy}

Fig. 1 shows an SEM image of the sample Sh-II-1 and indicated areas on the surface of which was carried out the elemental analysis. It is seen from Fig. 1, surface of the sample consists of micron size aggregates of clusters. Data of the elemental analysis (Table 1 ) shows that basically it is the clusters of carbon and silica, as well as pyrite $\left(\mathrm{FeS}_{2}\right)$, iron and aluminum oxides. There are areas with high carbon content $(\sim 81 \%$ and $\sim 96 \%$ for areas 4 and 5 , accordingly) and small amount of silicon and aluminum. At the same time there are areas with a high content of silica $(-22 \%$ Si for area 3). On Fig. 1 silica, carbon, and iron clusters have gray, black, and bright colors, accordingly. Sample ShF1 also investigated by SEM/EDX and showed results similar to 
Table 1. Element composition on surface of the shungite Sh-II-1 sample (at.\%).

\begin{tabular}{|c|c|c|c|c|c|c||}
\hline \hline No. Spectrum & $\mathrm{C}$ & $\mathrm{O}$ & $\mathrm{Si}$ & $\mathrm{Fe}$ & $\mathrm{S}$ & $\mathrm{Al}$ \\
\hline Spectrum 1 & 10.89 & 40.86 & 4.95 & 17.64 & 22.89 & 1.22 \\
Spectrum 2 & 25.50 & 32.49 & 9.64 & 14.42 & 15.87 & 1.10 \\
Spectrum 3 & 22.78 & 54.19 & 22.28 & $<0.01$ & 0.05 & 0.43 \\
Spectrum 4 & 81.46 & 14.22 & 3.64 & $<0.01$ & 0.03 & 0.44 \\
Spectrum 5 & 96.13 & 3.30 & 0.38 & 0.07 & 0.05 & 0.04 \\
\hline
\end{tabular}

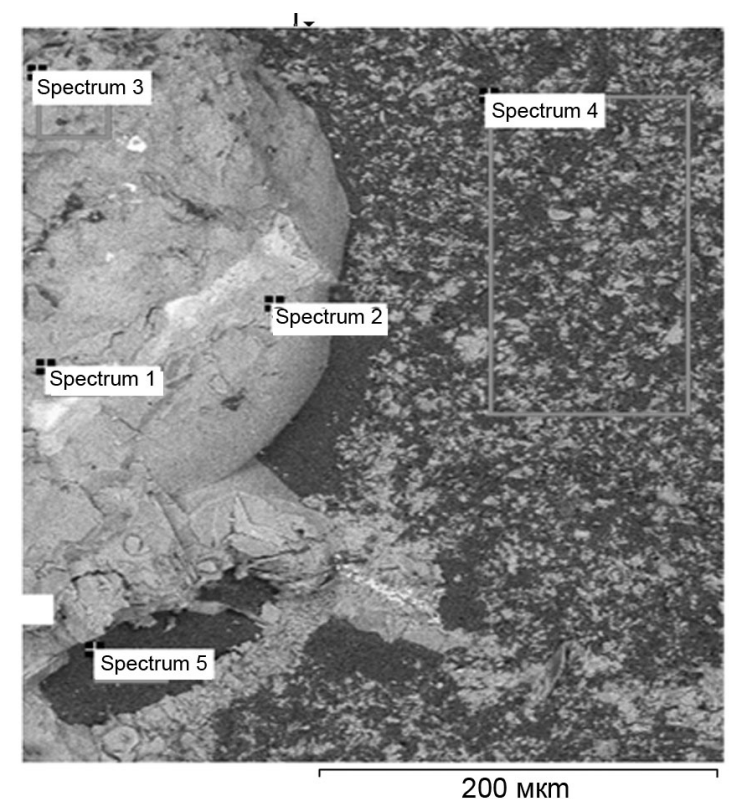

Fig. 1. Surface of the shungite Sh-II-1 sample with the allocated characteristic areas.

the sample Sh-II-1, but with a low content of iron.

As a result, Sh-II-1 and ShF1 are the heterogeneous shungite samples, which have as areas with a predominant content of one of the phases (carbon or silica), as well areas with nearly homogeneous mixing of these phases (Fig. 1, Spectrum 4).

\subsection{Raman Scattering}

To further detailing of the shungite structure, the Raman spectra of the sample Sh-II-1 was explored in the range from 300 to $3300 \mathrm{~cm}^{-1}$. It is known that the bands associated with silicon dioxide can be detected in the range of $300-600 \mathrm{~cm}^{-1}$. We could not observe such bands, supposedly because of the $\mathrm{SiO}_{2}$ clusters disordering and defects due to presence of impurities, for example, atoms of carbon. But in the range from 1100 to $1800 \mathrm{~cm}^{-1}$ were observed accurate $D$ and $G$-bands (Fig. 2) resulted from oscillations of carbon $s p^{2}$-hybridized atoms. It is known that band $G\left(1583 \mathrm{~cm}^{-1}\right)$ is

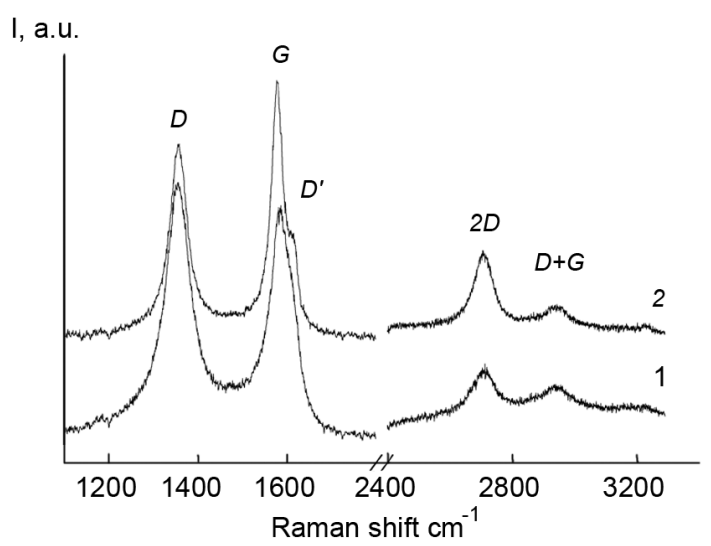

Fig. 2. RS spectra of the Sh-II-1 sample before (1) and after annealing at temperature $550^{\circ} \mathrm{C}(2)$.

related to the two-fold-degenerated mode of $\mathrm{E}_{2 \mathrm{~g}}$ symmetry in center of the Brillouin zone. $D$ band ( $1350 \mathrm{~cm}^{-1}$ ) [9], is a breathing mode of $\mathrm{A}_{1 \mathrm{~g}}$ symmetry that involves LO phonons near the $\mathrm{K}$-point of Brillouin zone [10, 11]. There also observed a high-frequency shoulder at a $G$ band - so-called $D$, band.

Spectrum in the range of $2400 \mathrm{~cm}^{-1}$. $3300 \mathrm{~cm}^{-1}$ shows the presence of the second order line $2 D$ and the combinations of lines $D+G$. The general view of spectrum and its parameters (Table 2) confirm that shungite is formed with well-ordered $s p^{2}$ hybridized carbon nanoclusters. From the ratio of integral intensities of bands $D$ and $G$, by using the empirical formula to estimate of the cluster size [12]:

$$
L_{a}(n m)=560 / E_{1}^{4}\left(I_{d} / I_{G}\right)^{-1},
$$

where $E_{1}$ - Raman spectrum excitation energy, we find that the size of nanoclusters of about $9.3 \mathrm{~nm}$. This is the first estimation of the size of carbon nanoclusters in shungite based on Raman data.

After vacuum annealing of this sample at $T=550{ }^{\circ} \mathrm{C}$, narrowing of $D$ and $G$ bands and redistribution of their intensities were 
Table 2. Spectral characteristics of the Sh-II-1 sample before and after annealing

\begin{tabular}{|c|c|c|c|c|c|c|c||}
\hline $\mathrm{n} / \mathrm{n}$ & $v_{D}, \mathrm{~cm}^{-1}$ & $\Gamma_{D}, \mathrm{~cm}^{-1}$ & $v_{G}, \mathrm{~cm}^{-1}$ & $\Gamma_{G}, \mathrm{~cm}^{-1}$ & $I_{D} \backslash I_{G}$ & $L_{a}, \mathrm{~nm}$ & $v_{D^{\prime}, \mathrm{cm}^{-1}}$ \\
\hline Initial & 1355.8 & 75.7 & 1583.4 & 59.2 & 1.47 & 9.3 & 1612.8 \\
Annealed & 1357.0 & 49.0 & 1578.3 & 34.1 & 1.09 & 12.5 & 1614.8 \\
\hline
\end{tabular}
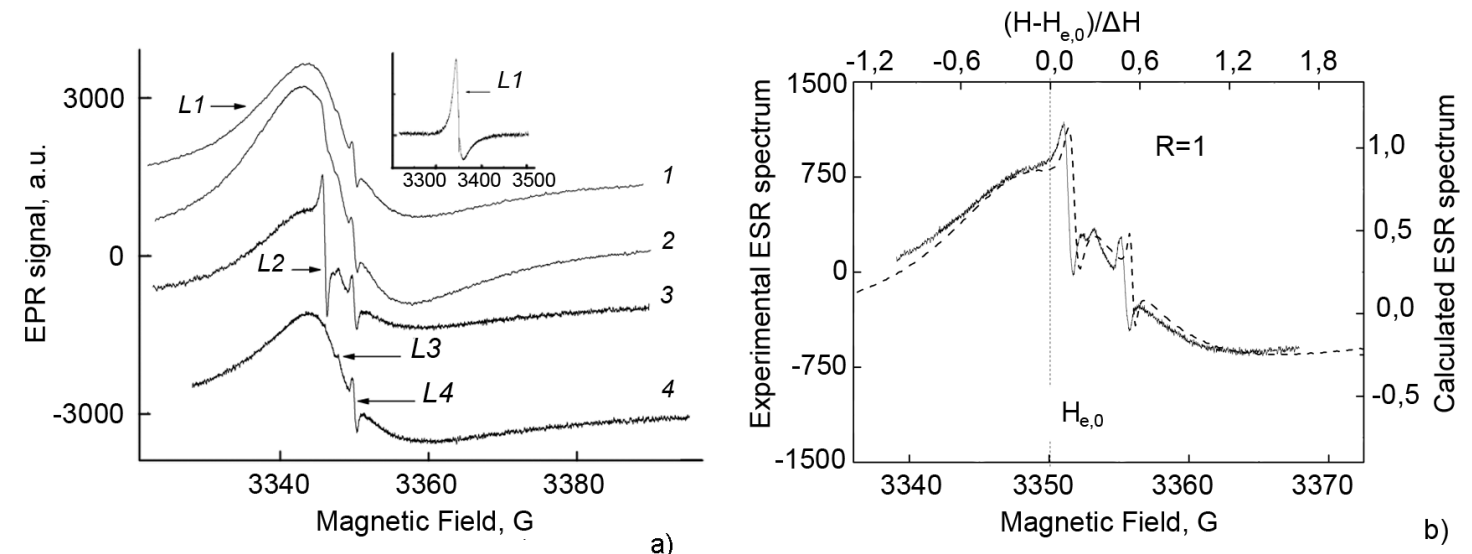

Fig. 3. a). EPR spectra of the ShF1 sample at different conditions: 1 - initial, $2-1 \mathrm{~h}$ pumping at RT, $3-0.5 \mathrm{~h}$ pumping at $130^{\circ} \mathrm{C}, 4-$ after $24 \mathrm{~h}$ storage in air. Insert: shape of the initial spectrum at higher scan. $v=9380 \mathrm{MHz} . T_{\text {meas. }}=300 \mathrm{~K}$; b) Theoretical analysis of the experimental spectrum. The dotted line indicates to the position $H_{\text {res }}$ for conduction electrons.

observed (Fig. 2). The $G$-band width decreased almost twice (Table 2), indicating to a decrease in disordering of the angles between carbon atoms in benzene rings. Such behavior is fairly typical for $s p^{2}$-hybridized carbon structures when annealing promotes structure ordering. We found that cluster size increased from $9.3 \mathrm{~nm}$ to $12.5 \mathrm{~nm}$ after annealing. This is a typical process of consolidation of carbon clusters where the number of defects decreases and the structure becomes more perfect.

With this in mind, one can conclude that the presence of silicon dioxide clusters does not affect significantly the processes of the temperature transformation of the shungite carbon structure.

\subsection{Electron paramagnetic resonance}

EPR measurements of a number of shungite samples show that in general its EPR spectrum consists of four resonance signals with different line widths and integral intensities. Fig. 3 a presents the EPR spectra of the sample ShF1, registered in various conditions. Lines $\mathrm{L} 1$, L3 and $\mathrm{L} 4$ were observed earlier in [13, 14]. Line L2 is registered for the first time and there is only in part of the samples $(\sim 20 \%)$, mainly after vacuum annealing at $\mathrm{T}=120-300^{\circ} \mathrm{C}$. Let us consider in detail the origin and characteristics of these EPR lines.
The line L1. This is the most intense line in the shungite samples, including in the sample ShF1 (Fig. 3a). It has asymmetrical, so called Dysonian shape of the EPR signal, which establishes its connection with electronic conductivity and indicates the high conductivity of the samples formed due to nanocarbon. The nature of this line undoubtedly proved in [13, 14]. The authors $[13,14]$ made the phenomenological description of this signal and have received the value of some parameters.

Here we present first rigorous theoretical description of the line shape L1, which takes into account the conductivity of the sample (Fig. 3b). For this purpose we used the theoretical expression given in $[15,16]$ for the conditions $d>\delta, \delta_{e}$, where $d$ is the thickness of the carbon cluster, $\delta$ - skin layer thickness determined by the conductivity and the microwave field frequency of the sample, and $\delta_{e}$ - electron diffusion path for spin relaxation time $T_{2}$.

In this case the EPR line shape is determined only by a single parameter $R^{2}=T_{\mathrm{D}} / T_{2}=\left(\delta / \delta_{\mathrm{e}}\right)^{2}$. The resonance field $H_{\text {res }}$ does not coincides with position at magnetic field axis $H$, where amplitude of the derivative of absorption signal is equal zero, as soon as a signal is a combination of absorption and dispersion. Consequently, g-factor 
of free electron can be found only after the fitting the calculated spectrum to the experimental one. By this reason $H_{\text {res }}$ is determined only after the fitting as a point at the $H$ axis, which corresponds to point zero at the upper dimensionless axis for the calculated spectrum in Fig. 3b. As a result, we find: $g=2.0030 \pm 1 \cdot 10^{-4} ; R=1 ; \Delta H_{1}=16.5 \mathrm{G}$. Comparison of the theory of spin resonance of conduction electrons with experiment for a number of other shungite samples (data not given) showed that the parameter $R$ varies widely from 0.8 to 5 .

The line L2. Origin of the symmetrical line L2 is connected, most likely, with isolated (not included in the aggregates) carbon clusters $\left(\mathrm{d}<<\delta, \delta_{e}\right)$, for which the line shape is not Dysonian but Lorentzian shape. Its parameters are: $g_{2}=2.0029$; $H_{2}=0.76 \mathrm{G}$. Sensitivity of the line L2 to pumping out (like coal [17]) shows that clusters are in contact with molecular oxygen due to the presence of open pores in a part of shungite sample. From the ratio of integral intensities $I_{\mathrm{L} 2} / I_{\mathrm{L} 1}$ can evaluate the relative concentration of isolated clusters as $\sim 2 \%$ in the sample ShF1.

Lines L3 and L4. These lines show correlated behavior as lines of separate spin system. Their intensity increases with pumping out of the sample at $T>120{ }^{\circ} \mathrm{C}$ (Fig. 3a, curves 3,4$)$. The spin concentration is $N_{\mathrm{s}} \cong$ $2 \cdot 10^{16} \mathrm{~cm}^{-3}$ estimated by comparing with reference sample $\mathrm{MgO}: \mathrm{Cr}^{3+}$. Parameters of these lines $\left(g_{3}=2.0019, \Delta H_{3}=1.0 \mathrm{G}\right.$; $g_{4}=2.00055, \Delta H_{4}=0.4 \mathrm{G}$ ) and their kinetics during annealing are very similar to the behavior of EPR signal formed in silica at oxygen deficiency [18]. This means that lines L3 and L4 are the components of the spectrum so called $E_{\gamma}$ ' centers with anisotropic g-factor and, therefore, the absorption peaks in the orientation $g_{\mathrm{II}}$ and $g_{\perp}$. Moreover, we found that line 4 resolutions into two narrow lines with effective g-factors of 2.0006 and 2.0004 at significant decreasing of the modulation amplitude. These findings coincide with precisely defined parameters of $E_{\gamma}$ ' centers, what are induced in silica by $\gamma$-irradiation [18, 19]. Finally the lines L3 and L4 (Fig. 3a) belong to the oxygen deficiency centers formed in silicon dioxide fraction of shungite under global geological factors.

In [14] the lines L3 and L4 were observed in shungite at the first time, but their interpretation was linked mistakenly to the impurities of fullerene in shungite without the necessary evidence.
The general spectrum in Fig. $3 \mathrm{~b}$ is calculated as a sum of the derivative of the Dyson function for L1, the derivative of the Lorentz function for signal L2, and the derivative of the Lorentz function with anisotropic g-factor averaged over angles for signals L3 and L4, with lines parameters listed above.

Finally the shungite EPR spectrum originates from three separate spin systems that are localized in both carbon (lines L1 and L2), and silicon dioxide (lines L3 and L4) fractions of shungite.

\section{Conclusions}

According to SEM/EDX data structure of the shungite samples studied is composed of mixture of aggregates of carbon and silica clusters, with inclusions of pyrite $\left(\mathrm{FeS}_{2}\right)$, iron and aluminum oxides. In areas of phase coexistence there is observed approximately uniform distribution of carbon and silica clusters.

Analysis of the Raman data shows that the carbon component of the shungite structure is formed by the $s p^{2}$-hybridized, well ordered carbon clusters with size about $9 \mathrm{~nm}$. Annealing of the samples leads to enlargement of carbon clusters up to $12 \mathrm{~nm}$ and their structure becomes more perfect.

The spin subsystem of free carriers is generated in nanocarbon part of shungite and gives a broad asymmetrical (with the Dyson shape) spin resonance signal L1 from carbon mesoclusters (aggregates), and the first reported narrow symmetric signal L2 from isolated clusters. Their characteristics are strongly determined based on the theory of spin resonance of conduction electrons.

For the first time the nature of the L3 and L4 lines of the shungite EPR spectrum is proved as oxygen-deficient $E_{\gamma}$ ' centers, in contrast to previous studies, where these signals are linked with fullerene molecules.

\section{References}

1. V.A.Melezhik, M.M.Filippov, A.E.Romashkin, Ore Geology Rev., 24, 135 (2004).

2. S.V.Kholodkevich, V.I.Berezkin, V.Yu.Davydov, Phys. Solid State, 41, 1291 (1999).

3. M.V.Avdeev, T.V.Tropin, V.L.Aksenov et al., Carbon, 44, 954 (2006).

4. N.I.Alekseev, O.V.Arapov, B.O.Bodyagin et al., Zh. Prikladnoi Khimii, 79, 1423 (2006).

5. A.Z.Zaidenberg, E.F.Dyukkiev, V.V.Kovalevski, Y.K.Kalinin, Electrochemistry, 27, 549 (1991).

6. D.Heymann, Carbon, 33, 237 (1995).

7. P.R.Buseck, Earthand Planetary Scie. Lett., 203, 781 (2002). 
8. G.Zhao, P.R.Buseck, A.Rougere, M.M.J.Treacy. Ultramicroscopy, 109, 177 (2009).

9. A.C.Ferrari, Solid State Commun., 143, 47 (2007).

10. F.Tuinstra, J.L.Koening, J.Chem.Phys., 53, 1126 (1970).

11. A.C.Ferrari, J.Robertson, Phys.Rev.B, 61, 14095 (2000).

12. L.G.Cancado, K.Takai, T.Enoki et al., Appl. Phys. Lett., 88, 163106 (2006).

13. M.A.Augustyniak-Jablokow, Yu.V.Yablokov, B.Andrzejewski et al., Phys.Chem. Minerals, 37, 237 (2010).

14. M.Yu.Yablokov, M.A.Augustyniak-Jablokow, W.Kempiniski et al., Phys.Stat.Solidi(b), 243, R66 (2006).
15. C.P.Poole, Jr., Electron Spin Resonance: A Comprehensive Treatise on Experimental Techniques, 2nd ed., Dover (1997).

16. N.P.Baran, V.M.Maksimenko, V.G.Gavriljuk et al., Phys. Rev. B, 48, 3224 (1993).

17. A.A.Konchits, B.D.Shanina, M.Ya.Valakh et al., J.Appl.Phys., 112, 043504 (2012).

18. D.L.Griscom, Nucl. Instrum. Meth. Phys. Res., B1, 481 (1984).

19. D.L.Griscom, Defects in $\mathrm{SiO} 2$ and related dielectrics: Science and Technology, edited by G. Pacchioni, L. Skuja, and D. L. Griscom Kluwer Academic, Dordrecht, 2000. 